Research Article

\title{
Utilization of ICTs for Availing Agricultural Information in District Charsadda, Khyber Pakhtunkhwa- Pakistan
}

\author{
Mohammad Tariq Aziz* and Ayesha Khan
}

Department of Agricultural Extension Education and Communication, The University of Agriculture, Peshawar, Khyber Pakhtunkhwa, Pakistan.

\begin{abstract}
Agricultural productivity has been improved through the utilization of modern techniques. Access to information in agriculture can be extended through ICTs which support and share knowledge. The research study was conducted to find out the role and utilization of information and communication technologies (ICTs) for availing agricultural information in the research area. District Charsadda was the universe of the study and Multi Stage Sampling technique was used to select respondents from three selected villages of Tehsil Shabqadar of District Charsadda, namely Hajizai, Katozai and Battagram. Through Proportional Allocation Technique a sample of 112 respondents on basis of $10 \%$ of total 1120 registered farmers was drawn to collect primary data through pre-tested and well-structured interview schedule. Collected data was analysized using Statistical Package for Social Sciences (SPSS). Results show that $42 \%$ of the respondents were above 35 years of age, majority (80\%) were literate having education from primary to above matric, $45.5 \%$ had farming experience of 1-10 years while 67\% have knowledge about agriculture extension department. All the respondents have knowledge about ICTs in which mobile phone was owned by $42.8 \%$ respondents in the research area followed by TV $(25 \%)$ and radio (17.0\%) while respondents who have telephone was recorded as $15.2 \%$ as a ICT tool. In the research area $7.1 \%$ of the respondent avail information through TV program, 9.9\% through radio broadcasts, $13.4 \%$ through mobile, $11.6 \%$ through internet, $14.3 \%$ through agriculture extension agents, $5.4 \%$ through private companies while $7.9 \%$ through fellow farmers. Only $41.1 \%$ of the respondents were aware of the programs about agriculture programs on mobile or internet in which more than half of the respondents (54.8\%) got awareness from extension agents, $19.5 \%$ by themselves, $17.4 \%$ by fellow farmers and $4 \%$ through private companies. Major problems encountered in receiving information were weak radio and TV signals, poor internet facility, less contact with extension workers and load shedding of electricity. Farmers considered that information obtained through ICTs are moderately sufficient and effective. Significant association existed of age and educational level with major problems faced whereas highly significant relationship was found for age and farming experience with application of information obtained while non-significant association existed with educational level. The study recommends that extension agents should create awareness and educate farmers on the use of modern ICT tools to obtain timely and relevant information to speed up adoption of innovations.

Received | September 09, 2020; Accepted | April 03, 2021; Published | June 24, 2021

*Correspondence | Mohammad Tariq Aziz, Department of Agricultural Extension Education and Communication, The University of Agriculture, Peshawar, Khyber Pakhtunkhwa, Pakistan; Email: tariqext@gmail.com

Citation | Aziz, M.T. and A. Khan. 2021. Utilization of ICTs for availing agricultural information in District Charsadda, Khyber PakhtunkhwaPakistan. Sarhad Journal of Agriculture, 37(3): 797-806.

DOI | https://dx.doi.org/10.17582/journal.sja/2021/37.3.797.806

Keywords | Information and communication technologies (ICTs), ICT tools, Dissemination of information, Effectiveness of agricultural information, Application of information
\end{abstract}




\section{Introduction}

$\mathrm{P}$ akistan being an agricultural country has a rich and wide range of natural resources. Increase in agricultural production is essential to enhance annual revenues and has a positive impact on food usage in the local market, which is due to the sustainable application of agriculture techniques (FAO, 2015). Pakistan's agrarian based economy has experienced many changes over previous years (FAO, 2017; Aldosari et al., 2017). Agriculture is one of the dominant sectors of the country which contribute $19.3 \%$ to the Gross Domestic Product (GDP) while 38\% of the labour force is engaged with agriculture (GoP, 2019-20). The growth rate in 201920 was 2.67 having missed the target of $3.5 \%$ but considerably higher than $0.58 \%$ growth achieved last year. The crop sector has witnessed positive growth of $2.98 \%$ during FY2020 mainly due to positive growth of $2.90 \%$ in important crops (GoP, 2019-20).

In Khyber Pakhtunkhwa 80\% inhabitants depend upon agriculture for their livelihood, contribute $22 \%$ to provincial GDP and provide employment to $44 \%$ of labour force (GoP, 2019-20). Key crops grown include maize, rice, wheat, sugarcane and tobacco along with fruits and vegetables (GoP, 2019-20; Wali, 2016).

The Ministry of Provincial Agriculture is responsible to carry out extension services in each province of Pakistan. Public extension has been playing an important role in enhancing the agriculture production, although the private sector also promotes agricultural development, as both the sectors are involved in transferring of technology (Malik and Khan, 2020). The agricultural extension services in the third world countries failed to effectively transfer agricultural technologies to farmers. The agriculture extension providers could not reach a large number of farmers which results in dissatisfaction with the services of public extension sector (Prinsley et al., 1994).

There is a huge difference between present productivity and the potential of our crops. Therefore, to increase agricultural production, application of science and technology is must and for this farmer should be trained and provided enough information about latest technologies (Waqas et al., 2017). The studies have shown that exposure to farmer's data can be major factor affecting the perception of farmers about adoption (Musingali and Zebron, 2014; Aldosari et al., 2017).

Agriculture extension in Pakistan uses a variety of methods to disseminate knowledge among famers (Butt et al., 2017) for agricultural development but it failed to obtain desired goals. The reasons for not having a significant impact are no incentives for extension staff, lack of agricultural planning, weak policies, and inadequate number of extension staff and lack of proper communication system (Khan et al., 2019). However, agricultural productivity can be improved through the utilization of modern techniques and access to information can be extended through ICT which support and share knowledge. In past, for the dissemination of information to rural people, radio, T.V and films were the main channels used while nowadays modern ICT tools like internet and mobile phones are utilized for information sharing (Wereh, 2012). ICT includes computer, internet, digital information and photography, social media, mobile phones, electronic media such as radio and T.V. ICTs are like a value addition into modern technology and its tools and resources are applied to create, store, transfer and manage information desired by target audiences.

ICT is among one of the key sources of getting updated information and plays an active role in the enhancement of agriculture especially in less developed countries. ICT is a collective term that is given to modern information technologies arising as a result of the combination of computers and telecommunications. ICT is a bridge of electronic and interactive source between farmers and extension staff (Anoop et al., 2015) and provides a great potential to disseminate information in a systematic way to the farmers by using mobile, television, radio, internet to help in making decisions regarding effective use of available resources to enhance profit (Ekbia and Evans, 2009; Ommani and Chizari, 2008).

In Pakistan, agriculture extension faces many challenges and the main obstacles faced include: less use of ICT, lack of funds, inadequate transportation, training and collaboration among different stakeholders. Farmers genuinely need the updated knowledge (Ogutua et al., 2014), and ICT can assume major role in providing timely information to farmers when needed (Aker et al., 2011). It seems indispen- 
sable, to strengthen services through use of electronic media. All over the world, ICT provides fast flow of relevant information and knowledge in agriculture to the farmers facilitating quick adoption of inputs and scientific methods and decisions about market (Kiplang, 1999). Effective and efficient use of ICT can enhance and raise agricultural production and income of farmers by providing more information and importance to the stakeholders (Rao, 2007). Thus, the present research was initiated to highlight the utilization of ICTs for availing agricultural information by the farmers in the study area.

\section{Objectives of the study}

- To examine the role of ICTs in disseminating agricultural information to the farmers.

- To explore the utilization of ICTs for availing agricultural information by the farmers.

- To pinpoint the constraints faced in the access and use of agricultural information through ICTs.

\section{Materials and Methods}

This research was conducted in District Charsadda and all the farmers were the population while Multistage Sampling Technique was used to draw the sample for the present study. Among the three Tehsils of District Charsadda, Shabqadar was selected purposively because most of the agriculture is in this tehsil. This tehsil is comprised of 12 union councils, out of which 3 union councils namely Katozai, Battagram and Hajizai were randomly selected for this study. A list of all registered farmers of Farm Services Center (FSC) was obtained from district agriculture office. Among the total registered farmers i.e. 1120 in the 3 selected union councils, $10 \%$ were selected as sampled respondents (keeping in view time and money constraints) which make up to 112 farmers. Proportional allocation technique was utilized to select the sample size at UC level. A pretested interview schedule was employed to collect data which was designed in such a way to collect accurate and complete data, having both open and close ended questions pertaining to the objectives of the study. Primary data was gathered through face to face interview while secondary data was solicited from published and unpublished source of information. Statistical Package for Social Sciences (SPSS) V-21 was used to analyze the collected data and results were presented in counts and percentages in frequency distribution tables. A 3- point Likert scale was used to measure the effectiveness of different variables (Likert, 1932). Weights were assigned such that high scores specify agreement and low score represents disagreement (Khan, 2012). Chi-square test at a significance level of $5 \%$ was employed to find out the association of various variables with each other.

\section{Results and Discussion}

\section{Personal characteristics/ demographic characteristics}

Age is an important factor which plays a vital role in the dissemination and adoption of latest technologies along with the diffusion of innovations among the farming community (Agwu et al.,2008). Data indicates that the majority i.e. $42.0 \%$ and $34.8 \%$ respondents were having the age above 35 years and $26-35$ years respectively while $23.2 \%$ respondents were in the age group of 18-25 (Table 1). More or less similar results were obtained by Aldosari et al. (2017) who reported that $34.4 \%$ and $33.3 \%$ respondents belonged to $25-$ 35 and 36-45 years of age, respectively. Researchers opined that younger farmers are less resistant to change and accepts and adopts new technologies readily and quickly, consequently speeds up the diffusion and adoption process (Habib et al., 2007). The study results indicate that if extension staff focus on respondents belonging to age 18-35 years and train them on utilizing ICTs for availing agricultural information it can improve adoption of new practices.

Table 1: Personal characteristic of the respondents.

\begin{tabular}{llllll} 
Age (in years) & No. & \% & Literacy status & No. & \% \\
\hline 18-25 & 26 & 23.2 & Illiterate & 22 & 19.6 \\
$26-35$ & 39 & 34.8 & Primary & 26 & 23.2 \\
Above 35 & 47 & 42.0 & Middle & 26 & 23.2 \\
Total & 112 & 100 & Matric & 21 & 18.8 \\
& & & Above matric & 17 & 15.2 \\
Farming experi- & No. & $\%$ & Total & 112 & 100 \\
ence (in years) & & & & & \\
1-10 & 51 & 45.5 & & & \\
$11-20$ & 41 & 36.6 & & & \\
Above 20 & 20 & 17.9 & & & \\
Total & 112 & 100 & & &
\end{tabular}

The data revealed that most of the respondents i.e. $80.4 \%$ were literate while the rest of $19.6 \%$ were illiterate. Among the literate, $28.9 \%$ respondents each were with primary and middle level education. Only $18.8 \%$ respondents were educated above matric while 23.4\% were matriculate in the study area. Hassan 
(1991) and Khan et al. (2019) stated that most of the illiterate farmers have little interest towards modern technologies and innovations. These results and observations are different from Pervaiz et al. (2013) where $(90 \%)$ of the farmers were illiterate involved highly in the profession of farming.

The total number of years of farmers' contribution and involvement in farming activities is termed as farming experience and according to Agwu et al. (2008) a distinctive component in farmer learning is his experience. Table 1 also shows the farming experience of the respondents in the selected three union councils namely Hajizai, Katozai and Battagram showing that a little less than half of the respondents i.e. $45.5 \%$ have farming experience of 1-10 years in agriculture. Farming experience of 11 to 20 years was recorded by $36.6 \%$ followed by 20 years of experience as reported by $17.9 \%$ of the respondents.

\section{Knowledge about agriculture extension department}

Wossen et al. (2017) opined that constant and regular contact between farmers and extension agent will help regulate their awareness about latest technologies and increases the probability/chance of accepting innovations by farming community. Table 2 shows the knowledge of respondents about agriculture extension department. The majority i.e. $67 \%$ of the total respondents have knowledge regarding agriculture extension department while $33.0 \%$ of the respondents were not aware. Majority i.e. 29.5\% in Hajizai were aware of agriculture extension department followed by $21.4 \%$ in Katozai and $16.1 \%$ in Battagram. Whereas, $12.5 \%$ respondents in Battagram were not aware of agriculture extension department, followed by $10.7 \%$ in Hajizai and $9.8 \%$ in Katozai. Almost opposite results are reported by Khan (2012) who stated that $37 \%$ respondents had acquaintance with extension agents as against $63 \%$ who have no contact with extension agent.

\section{Knowledge about ICT}

ICTs tools such as mobile phones, television, telephone and radio are helping farmers to change the exiting attitudes, share information with friends, question-answer session with extension officers and above all helps them to change the traditional pattern of cultivations. Table 3 represents the respondents' knowledge about information and communication tools (ICTs) which shows that farmers are having multiple ICTs tools. The results clearly indicate that all
$100 \%$ of the respondents in the research area were well familiar about the information and communication tools like mobile, TV, telephone and radio. Table 3 also shows the respondents who have ownership of different ICT tools. Mobile phone was owned by $42.9 \%$ respondents in the research area followed by TV (25\%) and radio (17.0\%) while respondents who have telephone was recorded as $15.2 \%$ as a ICT tool. The study results are dissimilar with Adegbidi et al. (2012) who conducted a study related to factors determining use of ICTs by rice farmers obtained that majority of respondents i.e. $90 \%$ use radio program followed by mobile calls (41\%), television (17\%) and mobile SMS (10\%) as a ICT tool.

Table 2: Respondents' knowledge about agriculture extension department.

\begin{tabular}{llllllll}
$\begin{array}{l}\text { Union } \\
\text { councils }\end{array}$ & \multicolumn{3}{l}{$\begin{array}{l}\text { Knowledge about agriculture } \\
\text { extension department }\end{array}$} & \multicolumn{2}{l}{ Total } \\
& \multicolumn{3}{c}{ Yes } & \multicolumn{2}{c}{ No } & & \\
& No. & $\%$ & No. & $\%$ & No. & $\%$ \\
Hajizai & 33 & 29.5 & 12 & 10.7 & 45 & 40.2 \\
Katozai & 24 & 21.4 & 11 & 9.8 & 35 & 31.2 \\
Battagram & 18 & 16.1 & 14 & 12.5 & 32 & 28.6 \\
Total & 75 & 67.0 & 37 & 33.0 & 112 & 100
\end{tabular}

Table 3: Respondents distribution regarding knowledge about ICT.

\begin{tabular}{lllllllll}
$\begin{array}{l}\text { Union } \\
\text { council }\end{array}$ & \multicolumn{3}{l}{$\begin{array}{l}\text { Knowledge } \\
\text { about ICT }\end{array}$} & \multicolumn{2}{l}{ ICT Tools Owned } \\
& & Yes & No & $\begin{array}{l}\text { Mo- } \\
\text { bile }\end{array}$ & TV & $\begin{array}{l}\text { Tele- } \\
\text { phone }\end{array}$ & $\begin{array}{l}\text { Ra- } \\
\text { dio }\end{array}$ & Total \\
Hajizai & No. & 45 & 0 & 23 & 12 & 8 & 2 & 45 \\
& $\%$ & 40.2 & 0 & 20.5 & 10.7 & 7.1 & 1.8 & 40.2 \\
Katozai & No. & 35 & 0 & 11 & 9 & 3 & 12 & 35 \\
& $\%$ & 31.2 & 0 & 9.8 & 8.0 & 2.7 & 10.7 & 31.2 \\
Batta- & No. & 32 & 0 & 14 & 7 & 6 & 5 & 32 \\
gram & $\%$ & 28.6 & 0 & 12.5 & 6.3 & 5.4 & 4.5 & 28.6 \\
Total & No. 112 & 0 & 48 & 28 & 17 & 19 & 112 \\
& $\%$ & 100.0 & 0 & 42.8 & 25 & 15.2 & 17.0 & 112
\end{tabular}

\section{Avail agricultural information and technical advice} through ICT

To improve efficiency, farmers need timely and trusted agricultural information and technical advice about inputs (seeds, pesticide and fertilizers), crop diseases and their solutions, comparative pricing of crops and inputs, and marketing techniques etc. It is clear from Table 4 that $69.6 \%$ of the respondent avail agriculture 
information and technical advice through ICTs. Table also shows the main sources of agriculture information availed were TV program, radio broadcasts, mobile phones, internet, agriculture extension agents, private companies and fellow farmers. Only $7.1 \%$ of the respondents avail information through TV program, 9.9\% through radio broadcasts, $13.4 \%$ through mobile, $11.6 \%$ through internet, $14.3 \%$ through agriculture extension agents, $5.4 \%$ through private companies while $7.9 \%$ through fellow farmers. Most of the respondents in Katozai i.e. 3.5\% and 4.5\% avail agriculture information and technical advice through TV program and radio broadcasts, respectively. Mobile phone and internet as a source of information was mentioned by $7.1 \%$ and $5.4 \%$ respondents, respectively in Hajizai. Agriculture extension agents occupies a central place in dissemination and transfer of timely agricultural information and practices to the farming community and it was observed that $7.1 \%$ in Hajizai, Katozai $5.4 \%$ and in Battagram by $1.8 \%$ of the respondents receive agriculture information and technical advice through agriculture extension agents. However, small number of respondents also receives agricultural information from private companies and fellow farmers in the study area. Chhachhar et al. (2014) explained that in developing countries use of communication tools like internet, mobile, radio and T.V for giving information and knowledge to farmers about agriculture has obtained fruitful results in technology adoption.
Respondents awareness about agricultural programs on mobile or internet

The majority of the respondents (58.9\%) have no mobile or no internet facilities and they are not aware of programs on agriculture information while $41.1 \%$ of the respondents have mobile or internet facility and are aware of different types of programs about agricultural information (Table 5). In the study area, different sources created awareness of programs regarding agriculture information or services on mobile or internet. Agriculture extension agents are the main source of farmers' awareness of programs about agricultural information on mobile or internet as reported by $54.4 \%$. Fellow farmers are also a vital source of awareness on programs about agriculture information which was recorded by $17.4 \%, 19.5 \%$ were aware of programs by themselves while $8.7 \%$ respondents' source of awareness was private companies. Majority of the farmers in Hajizai had extension agents as the source of awareness followed by fellow farmers as compared to other two union councils. The study results are dissimilar with Sousa et al. (2016) who mentioned that in developing world, mobile phones as a tool have a great potential for extension workers and farmer-to-farmer contact. Mobile phone is a novel approach for farmer-tofarmer exchange contributing to transformation of extension efforts enabling land use identification as well as more resilient, complete and democratic farming system.

Table 4: Respondents availing agriculture information and technical advice through ICT.

\begin{tabular}{|c|c|c|c|c|c|c|c|c|c|c|c|}
\hline \multirow{2}{*}{$\begin{array}{l}\text { Union coun- } \\
\text { cils }\end{array}$} & \multicolumn{5}{|c|}{ Avail agriculture information } & \multicolumn{5}{|c|}{ Source of information availed } & \multirow[t]{2}{*}{ Total } \\
\hline & Yes & No & Total & TV.P & R.B & Mobile & Internet & A.E & P.C & F.F & \\
\hline Hajizai & $36(32.1)$ & $9(8.1)$ & $45(40.2)$ & $2(1.8)$ & $3(2.7)$ & $8(7.1)$ & $6(5.4)$ & $8(7.1)$ & $3(2.7)$ & $6(5.3)$ & $36(32.1)$ \\
\hline Katozai & $24(21.4)$ & $11(9.8)$ & $35(31$ & $4(3.5)$ & $5(4.5)$ & $2(1.8)$ & $4(3$. & $6(5.4)$ & $1(0.9)$ & $2(1.8)$ & $24(21.4)$ \\
\hline Battagram & $18(16.1)$ & $14(12.5)$ & $32(28.6)$ & $2(1.8)$ & $3(2.7)$ & $5(4.5)$ & $3(2.7)$ & $2(1.8)$ & $2(1.8)$ & $1(0.8)$ & $18(16.1)$ \\
\hline Total & 78 (69.6) & $34(30.4)$ & 112 & $8(7.1)$ & $11(9.9)$ & $15(13.4)$ & 13(11.6) & $16(14.3)$ & $6(5.4)$ & $8(7.9)$ & $78(69.6)$ \\
\hline
\end{tabular}

Note: Parenthesis shows percentages. PC: Private Companies, FF: Fellow Farmers, RB: Radio Broadcasting, TV. P: Television Program, AE: Agriculture Extension

Table 5: Respondents awareness regarding programs on agricultural information on mobile or internet.

\begin{tabular}{lllllllll} 
Union & \multicolumn{2}{c}{ Awareness of programs on mobile or internet } & \multicolumn{3}{c}{ Source of awareness } & \multicolumn{2}{c}{ Total } \\
councils & Yes & No & Total & Extension agent & Yourself & Fellow farmer & P. C \\
Hajizai & $21(18.8)$ & $24(21.4)$ & $45(40.2)$ & $10(21.7)$ & $4(8.7)$ & $5(10.9)$ & $2(4.3)$ & $21(45.6)$ \\
Katozai & $12(10.7)$ & $23(20.5)$ & $35(31.2)$ & $7(15.3)$ & $3(6.5)$ & $1(2.2)$ & $1(2.2)$ & $12(26.1)$ \\
Battagram & $13(11.6)$ & $19(17.0)$ & $32(28.6)$ & $8(17.4)$ & $2(4.3)$ & $2(4.3)$ & $1(2.2)$ & $13(28.2)$ \\
Total & $46(41.1)$ & $66(58.9)$ & 112 & $25(54.4)$ & $9(19.5)$ & $8(17.4)$ & $4(8.7)$ & 46
\end{tabular}

Note: Parenthesis show percentages. 
Problems faced in receiving agricultural information through ICT

The respondents are facing different types of problems in receiving agricultural information through ICT like /no internet connection, weak signals of TV, weak signals of radio, poor/less contact with extension agents and electricity shortage as displayed in Table 6. Majority (17.0\%) of the respondents face weak TV and radio signals whereas $14.2 \%$ of the respondents have weak internet connection, $11.7 \%$ faced electricity shortage while $9.8 \%$ of the respondents have no contact and access to extension agents of their respective area. Rank order shows that weak TV and radio signals are ranked as 1 , no or poor internet connection as $2^{\text {nd }}$ followed by electricity shortage as $3^{\text {rd }}$ and poor contact with extension agents as $4^{\text {th }}$. Ali (2015) stated that respondents identified some barriers to the incorporation of ICTs such as lack of motivation, confidence, financial resources and ability among farmers, expensive equipment, poor networking and meager infrastructure for ICTs, electricity short fall, illiteracy, language barrier, and lack of training facilities and shortage of time.

\section{Sufficiency of agricultural information obtained from ICTS}

Table 7 shows that about $69.6 \%$ of the respondents were well satisfied about the sufficiency of agriculture information obtained from ICT while 30.4\% respondents were found unsatisfied. Regarding level of sufficiency majority i.e. $32.1 \%$ respondents perceived that agricultural information obtained from ICT was sufficient, $29.4 \%$ respondents stated moderately sufficient agriculture information obtained from ICT while only $8.1 \%$ respondents viewed highly sufficient agriculture information obtained from ICT.

\section{Level of effectiveness of agricultural information through ICTs}

Regarding level of effectiveness of agriculture information obtained from ICT in the research area which were categorized into three groups i.e. not effective, effective and very effective (Figure 1). A good number of the respondents i.e. $40.1 \%$ reported effective agriculture information obtained from ICT, 18.7\% respondents stated that very effective agriculture information while $10.4 \%$ respondents reported not effective agriculture information obtained from ICT. It is worth mentioning that the farmers perceived the agricultural information obtained from ICTs as effective (i.e. $40.1 \%$ effective and $18.7 \%$ very effective) and useful.

Association of age and educational level with major problems faced in receiving agricultural information through ICTs

The data in Table 8 indicates the relationship of age and educational level with major problems faced in receiving agricultural information by the farmers through ICTs employing Chi-square test.

Table 6: Problems faced by respondents in receiving agricultural information through ICT.

\begin{tabular}{|c|c|c|c|c|c|c|c|c|}
\hline \multirow{2}{*}{$\begin{array}{l}\text { Union } \\
\text { councils }\end{array}$} & \multirow[t]{2}{*}{ No } & \multirow[t]{2}{*}{ Yes } & \multicolumn{5}{|c|}{ Problem faced } & \multirow[t]{2}{*}{ Total } \\
\hline & & & $\begin{array}{l}\text { No/weak internet } \\
\text { connection }\end{array}$ & $\begin{array}{l}\text { Weak TV } \\
\text { signals }\end{array}$ & $\begin{array}{l}\text { Weak } \\
\text { radio signals }\end{array}$ & $\begin{array}{l}\text { Poor contact } \\
\text { with Ext-Agents }\end{array}$ & $\begin{array}{l}\text { Electricity } \\
\text { shortage }\end{array}$ & \\
\hline Hajizai & $36(32.2)$ & $9(8.0)$ & $7(6.3)$ & $9(8.0)$ & $8(7.1)$ & $6(5.4)$ & $6(5.4)$ & $36(32.2)$ \\
\hline Katozai & $24(21.4)$ & $11(9.8)$ & $7(6.3)$ & $6(5.4)$ & $5(4.5)$ & $3(2.7)$ & $3(2.7)$ & $24(21.4)$ \\
\hline Battagram & $18(16.1)$ & $14(12.5)$ & $2(1.7)$ & $4(3.6)$ & $6(5.4)$ & $2(1.7)$ & $4(3.6)$ & $18(16.1)$ \\
\hline Total & $78(69.7)$ & $34(30.3)$ & $16(14.2)$ & $19(17)$ & $19(17)$ & $11(9.8)$ & $13(11.7)$ & 112 \\
\hline Rank & & & 2 & 1 & 1 & 4 & 3 & \\
\hline
\end{tabular}

Note: Parenthesis show percentages.

Table 7: Respondents views regarding sufficiency of agricultural information obtained from ICTs.

\begin{tabular}{|c|c|c|c|c|c|c|c|}
\hline \multirow[t]{2}{*}{$\begin{array}{l}\text { Union } \\
\text { councils }\end{array}$} & \multicolumn{2}{|c|}{$\begin{array}{c}\text { Sufficient information } \\
\text { obtained }\end{array}$} & \multirow[t]{2}{*}{ Total } & \multicolumn{3}{|c|}{ Level of sufficiency } & \multirow[t]{2}{*}{ Total } \\
\hline & Yes & No & & Sufficient & Moderately sufficient & Highly sufficient & \\
\hline Hajizai & $36(32.1)$ & $9(8.9)$ & $45(40.2)$ & $18(16.1)$ & $15(13.3)$ & $3(2.7)$ & $36(32.1)$ \\
\hline Katozai & $24(21.4)$ & $11(9.8)$ & $35(31.2)$ & $12(10.7)$ & $10(8.9)$ & $2(1.8)$ & $24(21.4)$ \\
\hline Battagram & $18(16.1)$ & $14(12.5)$ & $32(28.6)$ & $6(5.3)$ & $8(7.1)$ & $4(3.6)$ & $18(16.1)$ \\
\hline Total & $78(69.6)$ & $34(30.4)$ & 112 & $36(32.1)$ & $33(29.4)$ & $9(8.1)$ & 78 \\
\hline
\end{tabular}

Note: Parenthesis show percentages. 
Table 8: Association of age and education with major problems faced in receiving agricultural information through ICTS.

\begin{tabular}{|c|c|c|c|c|c|c|c|c|}
\hline \multirow[t]{2}{*}{ Age } & \multicolumn{5}{|c|}{ Major problems faced } & \multirow[t]{2}{*}{ Total } & \multirow[t]{2}{*}{ Chi-Square } & \multirow[t]{2}{*}{ p-value } \\
\hline & $\begin{array}{l}\text { No/weak inter- } \\
\text { net connection }\end{array}$ & $\begin{array}{l}\text { WeakTV } \\
\text { signals }\end{array}$ & $\begin{array}{l}\text { Weak radio } \\
\text { signals }\end{array}$ & $\begin{array}{l}\text { Poor contact with } \\
\text { Ext-Agents }\end{array}$ & $\begin{array}{l}\text { Electricity } \\
\text { shortage }\end{array}$ & & & \\
\hline $18-25$ & $2(1.8)$ & $1(0.8)$ & $0(0)$ & $0(0)$ & $4(3.6)$ & $26(23.2)$ & \multirow{4}{*}{38.109} & \multirow[t]{4}{*}{0.000} \\
\hline $26-35$ & $4(3.6)$ & $8(7.1)$ & $9(8.0)$ & $7(6.3)$ & $4(3.6)$ & $39(34.8)$ & & \\
\hline Above 35 & $10(8.9)$ & $10(8.9)$ & $10(8.9)$ & $4(3.6)$ & $5(4.5)$ & $47(42.0)$ & & \\
\hline Total & $16(14.2)$ & 19(17.0) & 19(17.0) & $11(9.8)$ & $13(11.6)$ & 112 & & \\
\hline \multicolumn{9}{|c|}{ Educational status } \\
\hline Primary & $5(4.5)$ & $6(5.4)$ & $6(5.4)$ & $1(0.9)$ & $4(3.6)$ & $26(23.2)$ & \multirow[t]{5}{*}{32.279} & \multirow[t]{5}{*}{0.040} \\
\hline Middle & $2(1.8)$ & $5(4.5)$ & $6(5.4)$ & $6(5.4)$ & $1(0.9)$ & $26(23.2)$ & & \\
\hline Matric & $0(0)$ & $3(2.7)$ & $3(2.7)$ & $3(2.7)$ & $3(2.7)$ & $21(18.8)$ & & \\
\hline Above Matric & $3(2.7)$ & $1(0.9)$ & $0(0)$ & $0(0)$ & $3(2.7)$ & $17(15.2)$ & & \\
\hline Total & $16(14.2)$ & $19(17.0)$ & $19(17.0)$ & $11(9.8)$ & $13(11.6)$ & 112 & & \\
\hline
\end{tabular}

Source: Calculated by Author. Note: Parenthesis show percentages.

The Chi-square value is 38.109 and $\mathrm{P}$-value as 0.000 for age which shows highly significant association indicating that old age farmers face more problems in obtaining agriculture information through ICTs as compared to the young ones in the research area. Whereas, Chi-square value is 32.279 and $\mathrm{P}$-value is 0.040 for educational level which is less than the significance value i.e. 0.05 showing that there is significant association between the two attributes. It indicates that more educated respondents faced few problems as compared to less educated respondents in the study area. Respondents suggested that the extension department should take the necessary steps for resolving the problems regarding reception of agricultural information through ICTs.

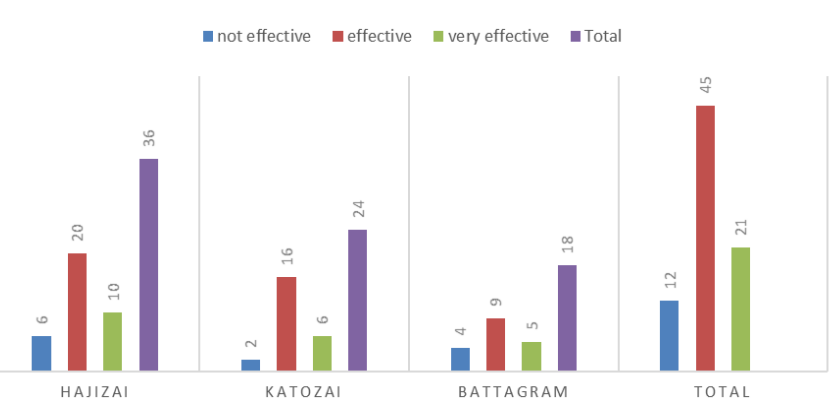

Figure 1: Level of effectiveness of agricultural information.

Association of personal characteristics with application of agriculture information obtained from ICTs

Table 9 show the result of Chi-square test used to assess the link between personal characteristics and application of agriculture information obtained from ICTs. The results indicate that there exists significant relationship between age and application of agriculture information obtained through ICT as

clear by $\mathrm{P}$-value $=0.002$. It is therefore concluded that as the age of respondent increases the application of agricultural information obtained from ICT also increases. Similar results were achieved by Aldosari et al. (2017) where he also got significant association of age with application of agriculture information obtained from radio and T.V. Contrary to this, Muhammad et al. (2012) reported that age is nonsignificantly associated with application of agriculture information received through radio and T.V.

Table 9 indicates that there exists a non-significant association between educational level of the respondents and application of agriculture information obtained from ICTs as $\mathrm{P}$-value $=0.410$. It means that irrespective of the educational level of respondents they apply the information obtained from ICT.

The results in Table 9 also show that there exists significant association between farming experience and application of agriculture information obtained from ICTs as indicated by $\mathrm{P}$-value $=0.003$. Therefore, it means that as the farming experience increases the application of agriculture information obtained by ICT also increases and it is concluded that experienced farmers tend to apply information more than less experienced farmers. Similar results were reported by Muhammad et al. (2012) who also mentioned the presence of significant association between farming experience and application of agriculture information received through radio. However, opposite results were achieved by Aldosari et al. (2017). 
Table 9: Association of personal characteristics with application of agriculture information obtained from ICTs.

\begin{tabular}{|c|c|c|c|c|c|}
\hline \multirow[t]{2}{*}{ Age } & \multicolumn{2}{|c|}{$\begin{array}{l}\text { Apply Information } \\
\text { obtain from ICTs }\end{array}$} & \multirow[t]{2}{*}{ Total } & \multirow[t]{2}{*}{$\begin{array}{l}\text { Chi- } \\
\text { Square }\end{array}$} & \multirow[t]{2}{*}{ pvalue } \\
\hline & Yes & No & & & \\
\hline $18-25$ & $9(8.0)$ & $17(15.2)$ & $26(23.2)$ & \multirow[t]{5}{*}{12.809} & \multirow[t]{4}{*}{0.002} \\
\hline $26-35$ & $18(16.1)$ & $21(18.8)$ & $39(34.8)$ & & \\
\hline Above 35 & $35(31.3)$ & $12(10.7)$ & $47(42.0)$ & & \\
\hline Total & $62(55.4)$ & $50(44.6)$ & 112 & & \\
\hline \multicolumn{5}{|c|}{ Educational Level } & \\
\hline Primary & $17(15.2)$ & $9(8.0)$ & $26(23.2)$ & \multirow[t]{5}{*}{3.970} & \multirow[t]{5}{*}{0.410} \\
\hline Middle & $12(10.7)$ & $14(12.5)$ & $26(23.2)$ & & \\
\hline Matric & $9(8.0)$ & $12(10.7)$ & $21(18.8)$ & & \\
\hline $\begin{array}{l}\text { Above } \\
\text { Matric }\end{array}$ & $10(8.9)$ & $7(6.3)$ & $17(15.2)$ & & \\
\hline Total & $62(55.4)$ & $50(44.6)$ & 112 & & \\
\hline \multicolumn{6}{|c|}{ Farming experience } \\
\hline $1-10$ & $24(21.4)$ & $27(24.1)$ & $51(45.5)$ & \multirow[t]{4}{*}{11.851} & \multirow[t]{4}{*}{0.003} \\
\hline $11-20$ & $20(17.9)$ & $21(18.8)$ & $41(36.6)$ & & \\
\hline Above 20 & $18(16.1)$ & $2(1.8)$ & $20(17.9)$ & & \\
\hline Total & $62(55.4)$ & $50(44.6)$ & 112 & & \\
\hline
\end{tabular}

Source: Calculated by Author.

Note: Parenthesis shows percentages.

\section{Conclusions and Recommendations}

Most of the respondents were in the middle age group and majority of the respondents were literate and have farming experience of 1-10 years. In the study, most of the respondents are well aware about agriculture extension and have knowledge about ICT tools like mobile, T.V, radios and telephone etc. The study concludes that farmers utilize these ICT tools to obtain agricultural information and they are aware of different agricultural programs available on mobile or internet. Major problems faced in receiving agricultural information through ICT tools were weak radio and T.V signals, no/weak internet connection, less contact with the extension agents and load shedding of electricity. It is concluded that farmers considered that information obtained through ICTs is moderately sufficient and effective. Significant association existed for age and educational level with major problems faced while highly significant relationship was found for age and farming experience with application of information obtained while nonsignificant association existed with educational level.

1. Government may provide and improve the provision of internet facilities in the rural areas and resolving the issue of weak signals of T. $V$ and radio by installing boosters in different locations to enhance accessibility to different ICT facilities.

2. Effective utilization of ICT has potential to make farmers prosperous therefore; extension agents should create awareness regarding use of ICT tools among the farmers and should educate farmers on the use of modern ICT tools to obtain relevant and timely agricultural information.

3. Extension agents should generate awareness among young and middle-aged farmers about ICT services and enhance their participation in utilizing ICT tools for availing updated agricultural information.

Regarding importance of various ICT tools, the agricultural information department should produce and broadcast different useful programs for agricultural development for speedy dissemination of up to date knowledge and information.

\section{Novelty Statement}

Novelty of this research study is to educate and familiar the farmers community in the District Charsadda, KP- Pakistan about the knowledge and use Information and Communication Technologies (ICT) tools. Mostly the farmers in the study area used/utilized mobile and Internet for obtaining agricultural information which they considered is moderately sufficient and effective.

\section{Author's Contribution}

Mohammad Tariq Aziz: Principal author who conducted research, collected the field data and performed the analysis.

Ayesha Khan: Major Supervisor, planned the research, interpreted the results and wrote the manuscript.

\section{Conflict of interest}

The authors have declared no conflict of interest.

\section{References}

Adegbidi, A.B., R. Mensah, F. Vidogbena and D. Agossou. 2012. Determinants of ICTS use by rice farmers in Benin: From the perception of ICTs characteristics to the adoption of the technology. J. Res. Int. Bus. Manage., 2(11): 273-284.

Agwu, A.E., J.N. Ekwueme and A.C. Anyanwu. 
2008. Adoption of improved agricultural technologies disseminated via radio farmer programme by farmers in Enugu State, Nigeria. Afr. J. Biotech., 7(9): 1277-1286. [Online] http://www.bioline.org.br/request?jb08215. Accessed on: April 10, 2019.

Aker, O.J., E.E. Ajayi and L. Gunn. 2011. The role of communication in dissemination of improved agriculturetechnologyinBossolocalgovernment area of Niger, Nigeria. J. Agric. Ext., 13: 66-72. http://www.sciencedirect.com/ science/article/ pii/ S1658077x1730070x-660015. Accessed on Oct, 2019.

Aldosari, F., M.S. Al-Shunaifa, M.A. Ullah, M. Muddassir and M.A. Noor. 2017. Farmers' perceptions regarding the use of information and communication technology (ICT) in Khyber Pakhtunkhwa, Northern Pakistan. J. Saudi Soc. Agric. Sci., Available at: Retrieved on: 25 th Dec. 2019. https://doi.org/10.1016/j. jssas.2017.05.004

Ali, M., 2015. The role of farm services center in enhancing wheat production in Kurram Agency. Unpublished M.Sc (Hons) thesis, Department of Agricultural Extension Education and Communication, The University of Agriculture, Peshawar. pp. 3.

Anoop, M., N. Ajjan, K. Amp and R. Ashok. 2015. ICT based market information services in Kerala-Determinants and barriers of adoption. Econ. Aff., 27(2): 55-65.

Butt, M.T., G. Qijie, M. Luqman, M. Zakaria and Y. Hassan. 2017. Mode of ICTs application in plant production and protection technology in rural Punjab-Pakistan. Transylvanian Rev., 25(4): 13-18.

Chhachhar, A.R., B. Querestic, G.M. Khush and S. Ahmad. 2014. Impact of ICTs in agriculture development. J. Basic Appl. Sci. Res., 4(2014): 281-288.

Cochran, W.G., 1977. Sampling techniques. $3^{\text {rd }}$ Edition. John Wiley and sons, New York. pp. 37-40.

Ekbia, H.R. and T.P. Evans. 2009. Regimes of information: Land use, management, and policy. Inf. Soc., 25(5): 328-343. https://doi. org/10.1080/01972240903212789

FAO, 2015. (Food and Agriculture Organization of the United Nation). 2015. Agriculture and fisheries Department. pp. 45-50.

FAO, 2017. (Food and Agriculture Organization of the United Nation). 2017. Agriculture and Fisheries Department. pp. 51-56.

GoP, 2019-20. (Government of Pakistan). 201920. Pakistan Economic Survey-2019-20. Finance Division, Economic Adviser's Wing, Islamabad, Pakistan. pp. 18.

GoPK, 2019-20. (Government of Khyber Pakhtunkhwa). 2019-20. Agriculture Policy, Khyber Pakhtunkhwa. Planning and Development Department. Pp. 1-10.

Habib, M., Z. Khan, M. Iqbal, M. Nawab and S. Ali. 2007. Role of farmer field school on sugarcane productivity in Malakand Pakistan. African Crop Science conference proceeding. Afr. Crop Sci. Soc., pp. 1443-1446.

Hassan, M.Z.Y., 1991. A study in the adaptation of plant protection measures among the mango grower of Tehsil Muzaffargarh. M.Sc. (Agri. Ext) Thesis, University of Agriculture, Faisalabad, Pakistan. pp. 4-5.

Khan,A.,2012.Analysis ofbarrierstocommunication regarding production technology among researchers, extension personnel and farmers in Khyber Pakhtunkhwa: Pakistan. Unpublished PhD dissertation, Department of Agricultural Extension Education and Communication, The University of Agriculture, Peshawar-Pakistan. pp. 62-63.

Khan, A., Z.A. Khan, U. Pervaiz and M. Iqbal. 2019. Extension agents perceptions regarding constraints to adoption of improved agricultural practices by farmers. Sarhad J. Agric., 35(2): 342-348. https://doi.org/10.17582/journal. sja/2019/35.2.342.348

Khan, M.Z., A. Khaliq, Rahmatullah, M. Iqbal, U. Pervaiz and A. Khan. 2019. Model farm service centers' contribution in enhancing peach production: evidence from remote areas of Northern Pakistan. Int. J. Biosci., 15(1): 302309.

Kiplang, J., 1999. An analysis of the opportunities for information technology in improving access, transfer and the use of agricultural information in the rural areas in Kenya. Library Manage., 20(2):115-127. https://doi. org/10.1108/01435129910251575

Likert, R., 1932. A technique for the measurement of attitudes. Arch. Psychol., 22(140): 1-55.

Malik, S. and A. Khan. 2020. Gap analysis of farmers' capacity building by public and private agriculture extension sectors in Central Plain 
Valley of Khyber Pakhtunkhwa, Pakistan. Sarhad J. Agric., 36 (3):992-1000. https://doi. org/10.17582/journal.sja/2020/36.3.992.1000

Muhammad, S., T.E. Lodhi and G.A. Khan. 2012. In depth analysis of electronic media to enhance their role in agricultural technology transfer in the Punjab-Pakistan. Pak. J. Agric. Sci., 49: 221-227.

Musingali, M.C.C. and S. Zebron. 2014. The role of information and communication technology in rural socio-economic development in Africa. Int. J. Publ Pol. Admin. Res., I: 38-46.

Ogutua, J.J., D.J. Okellof and J. Otienoc. 2014. Impact of Information and communication technology- based market information services on small holder farm input use and productivity: The case of Kenya. World Level, 64(4): 311-321. https://doi.org/10.1016/j. worlddev.2014.06.011

Ommani, A.R. and M. Chizari. 2008. Information dissemination system (IDS) based e- learning in agricultural of Iran (Perception of Iranian extension agents). World Acad. Sci. Eng. Technol., 38: 468-472.

Pervaiz, U., F. Khan, D. Jan, Z. Huma and M. Z. Khan. 2013. An analysis of sugarcane production with reference to extension services in union council Malakandher-Peshawar. Sarhad J. Agric., 29(1): 37-42.

Prinsley, R., J. Dore, N. Marks, N.M. Gukian and P. Thompson. 1994. The role of private sector in extension. A working paper. Rural Ind. Res. Dev. Corp. Occas. Paper No. 94/3. Australia.pp. 7-11.
Rao, N.H., 2007. A framework for implementing ICTs in agricultural development in India. Technol. Forecast. Soc. Change, 74(4): 491-518. https://doi.org/10.1016/j.techfore.2006.02.002

Sousa, F., G. Nicoley and R. Home. 2016. Information technologies as a tool for agricultural extension and farmer-to-farmer exchange: Mobile-phone video use in Mali and Burkina FASO. Int.J. Educ. Dev. Inf. Commun. Technol., 12: 19-36.

Wali,N.,2016.An analysis of farmers'empowerment through the project, meat and dairy development program, Khyber Pakhtunkhwa. M.Sc (H) thesis, Department of Agricultural Extension Education and Communication, The University of Agriculture, Peshawar, Khyber Pakhtunkhwa, Pakistan. pp.7.

Waqas, M.A., I. Khan, M.J. Akhter, M.A. Noor and U. Ashraf. 2017. Exogenous application of plant growth regulators (PGRs) induces chilling tolerance in short-duration hybrid maize. Environ. Sci. Pollut. Res., 24: 11459-11471. https://doi.org/10.1007/s11356-017-8768-0

Wereh, H., 2012. The role of ICTs in dissemination of information on ecological organic agriculture. Biovision farmer communication programme, Kakamega, Kenya. pp. 67-72.

Wossen, T., T. Abdoulaye, A. Alene, S. Feleke, A. Olanrewaju and V. Manyong. 2017. Impact of extension access and cooperative membership on technology adaptation and household welfare in Nigeria. J. Rural Stud., 54(3): 223-233. https:// doi.org/10.1016/j.jrurstud.2017.06.022 